\title{
The Influence of Authentic Leadership and Work Environment on Teachers Performance
}

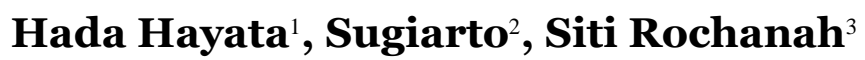

DOI: $10.35445 /$ alishlah.v13i1. 564

\section{Article Info}

Keywords:

Authentic Leadership

Work Environment

Performance

Kata kunci:

Kepemimpinan Otentik Lingkungan Kerja Kinerja

\begin{abstract}
This research was conducted to find that authentic leadership and work environment influence partially and simultaneously on the performance of Bekasi City Junior High School teachers. This study using a methodology with descriptive quantitative approach regression models. The population in this study was 306 teachers, and the sample was taken using the Slovin formula with an error rate of $5 \%$ so that there were 75 teachers. The instrument used was a questionnaire distributed via Google Form based on the Likert scale. At the same time, hypothesis testing is obtained based on the results of the t-test, $\mathrm{F}$ test and the coefficient of determination test. The results prove that there are several conclusions, namely: (1) authentic leadership has a positive effect on the performance of Junior High School teachers; (2) The work environment has a positive and significant effect on the performance of Junior High School teachers; (3) Authentic leadership and work environment simultaneously influence the performance of Junior High School teachers with the results of the test value of the coefficient of determination of 0.673 or $67.3 \%$, meaning that authentic leadership and work environment have an influence on performance by $67.3 \%$ and the rest $32.7 \%$ is influenced by variables not studied.
\end{abstract}

\begin{abstract}
Abstrak
Penelitian ini dilakukan untuk membuktikan bahwa kepemimpinan otentik dan lingkungan kerja berpengaruh secara parsial maupun simultan terhadap kinerja guru Sekolah Menengah Pertama Kota Bekasi. Dalam penelitian ini menggunakan metodologi dengan pendekatan kuantitatif deskriptif dengan model regresi linier berganda. Populasi pada penelitian ini sebesar 306 guru dan diambil sampel dengan rumus Slovin dengan tingkat kesalahan 5\%, sehingga berjumlah 75 guru. instrument yang digunakan berupa angket yang disebarkan melalui google form berdasarkan skala likert. Sedangkan pengujian hipotesis didapat berdasarkan hasil uji-t, uji F dan Uji Koefisien determinasi. Hasil membuktikan terdapat beberapa kesimpulan, yaitu: (1) kepemimpinan otentik berpengaruh positif terhadap kinerja guru Sekolah Menengah Pertama; (2) Lingkungan kerja berpengaruh positif dan signifikan terhadap Kinerja guru Sekolah Menengah Pertama; (3) Kepemimpinan otentik dan Lingkungan Kerja berpengaruh secara simultan terhadap kinerja guru Sekolah Menengah Pertama dengan hasil nilai uji koefisien determinasi sebesar o,673 atau 67,3\%, artinya kepemimpinan otentik dan lingkungan kerja memberikan pengaruh
\end{abstract}

\footnotetext{
${ }^{1}$ State University of Jakarta, Jakarta, Indonesia

Email: haddahayata@gmail.com

${ }^{2}$ State University of Jakarta, Jakarta, Indonesia

Email: sugiarto@unj.ac.id

${ }^{3}$ State University of Jakarta, Jakarta, Indonesia

Email: sitirochanahunj@gmail.com
} 
terhadap kinerja sebesar $67,3 \%$ dan sisanya $32,7 \%$ dipengaruhi oleh variabel yang tidak diteliti.

\section{INTRODUCTION}

Indonesia has realised a lot about the importance of the role of an educated society as a form of national morality to increase development towards an advanced and civilised society. As illustrated in the preamble of the 1945 Constitution of the Republic of Indonesia, this awareness, namely the Unitary State of the Republic of Indonesia, aims to educate the nation's life. In line with this, one form of actualisation of the primary duties of teachers as professionals in the formation of Law Number 20 of 2003 concerning the National Education System, Law No. 14 of 2005 concerning Teachers and Lecturers and Government Regulation Number 19 of 2005 concerning Standards. National Education. This law that the Government has drafted is expected to bridge teachers' ability to develop their abilities, both pedagogical, professional, personal, and social skills, sustainably. However, it is hoped that this can meet the future needs and demands related to competence as a teacher.

In the world of education, the role of the principal is no less important in supporting the process of improving the quality of education in schools. Even his figure is a determinant of the success of the organisation he leads. School success can be achieved if it is lead by the right person, namely the principal, who can carry out his functions and roles properly, but it should be noted that this can be done if the principal has sufficient leadership skills. Talking about leadership skills, of course, cannot be separated from the leadership style adopted by the principal. The leadership style reflects the personality of a leader himself and how the leader can bring work motivation and comfort to his subordinates so that the achievement of organisational goals can be accomplished. Therefore, choosing the right leadership style by the leader will significantly influence the success of the organisation. As for the various styles of existing leadership, authentic leadership is the basis or foundation of every leadership style. According to Robbins \& Judge (2017), "Leadership is the ability to influence a follower toward achieving a vision or set of goals".

Apart from the principal, a comfortable school environment can also be a factor in improving teacher performance. Creating a comfortable environment is an essential task for all educational institutions because creating a good environment can make it easier for teachers to carry out their duties appropriately and reasonably. Integrity is an essential foundation for cultural empowerment and a valuable quality for authentic leaders in a work environment. An organisation generally conforms to the values of its leader. When leaders lead with integrity, they tend to get integrity in return. Integrity is an essential foundation for cultural empowerment and a valuable quality for authentic leaders in a work environment. An organisation generally conforms to the values of its leader. When leaders lead with integrity, they tend to get integrity in return.

According to George \& Jones (2012), authentic leadership provides wisdom to emerging leaders. A truly effective leadership style is shaped by a person's values, experience and choices. Authentic leadership gives emerging leaders the wisdom to form a truly effective leadership style. It depends on one's values, experiences and choices. It is reflected in the seven elements of the education ecosystem. First, a conducive school is needed to create an effective school. A school is a place in which there is an interdependent relationship between humans and their environment. A conducive school is a fun place for humans who interact in it, students, teachers, educators, parents of students, and other actors.

Another thing that is very important in realising the success of schools in improving teacher performance is the work environment. The work environment is one of the factors that affect teacher performance. Teachers should feel a comfortable and conducive working atmosphere in the school. The comfort of the work environment of an educational institution such as a school dramatically influences the development of all these stakeholders, especially in the achievement of student academic achievement. According to Robbins \& Judge (2013), the environment is the institutions or forces that potentially affect the organisation's performance. Therefore, the work environment is an 
outside institution or force that can affect organisational performance. Then the work environment is divided into two types, namely the general environment and a particular environment.

Teacher performance is a significant factor in achieving educational goals because teachers are at the forefront of the world of education. Quality learning is highly reflected in the teacher's performance. Thus, the better the teacher's performance, the better the learning in the classroom. According to Gibson et al. (2009), performance results from work-related organisational goals (such as quality efficiency and other effectiveness standards). Colquitt et al. (2017), work performance is formally defined as the value of a set of employee behaviours that contribute positively or negatively to the realisation of organisational goals. Thus, performance is the value of employees' behavior in performing tasks, main functions, and functions under goals. Established by an organisation, Armstong (2020) describes the performance can be measured in several dimensions in terms of the competencies required. In achieving the target level of performance in a particular job or at a particular level, the organisation where performance can be measured in several dimensionsneeded in increasing competence to achieve performance under targets in completing specific jobs. Another thing that requires teachers' quality, competence, and professionalism to be improved is that there is no scientific evidence that there is a linear relationship between increasing qualifications and certification of the teaching profession on student learning outcomes. It is partly due to the absence of the Teacher Competency Test system to assess student learning outcomes, not implementing valid, reliable, transparent, and sustainable teacher performance assessments.

While this is supported by previous research, Purwanto et al. (2020), the analysis and processing of research data show that transactional and authoritative leadership styles at MTS madrasah positively affect, while Transformational and authentic do not have a significant effect on teacher performance. While different from the research results from Ribeiro et al. (2018), there is a positive influence between authentic leadership variables and performance. This study emphasises employee commitment. Okasheh \& AL-Omari (2017) There is a positive influence of the work environment on employee performance. Demus et al. (2015) state that the work environment has a positive effect on employee performance. Wang et al. (2014) found that authentic leadership has a positive effect on performance. Then, Lestary (2017) state there is a positive influence of the work environment on employee performance. Darvish \& Rezaei (2011) found a positive influence of authentic leadership variables on employee commitment.

The difference based on comparison with relevant research is that researchers focus more on the authentic leadership of State Junior High School principals in Bekasi City. In contrast, researchers do not examine other leadership styles in various principal leadership styles such as transformational, transactional and others. Variable work is an independent variable between the influence of each variable. Here, it is focused on teacher performance in schools. This study was conducted to show that authentic leadership and work environment affect teacher performance based on findings and facts. The results of this study are expected to be helpful in understanding what the principal needs to prepare in leading, managing, and organising. It is hoped that creating the atmosphere in the work environment is more comfortable. This situation prevents teachers from experiencing a decline in performance in class. The teachers must be able to create a comfortable and conducive environment to support the improvement of teacher performance. The presence of teachers is significant in the continuity of education in schools.

\section{METHODS}

This study used a survey method with a quantitative approach and path analysis techniques. The research data were collected through sampling from the population. This study intends to find the effect of three variables, namely two independent variables: authentic leadership (X1) and work environment (X2) and the dependent variable: Teacher performance (Y). The affordable population that is the target of this study is junior high school teachers in Bekasi. The number of teachers in eight schools in Bekasi was 306 teachers, and the number of research samples was determined using 
the Slovin formula at an error rate of $5 \%$. So the number of samples used was 75 teachers who were taken randomly by using proportionate random sampling. The data collection used in this study is an instrument in the form of a closed questionnaire, in which the respondents just choose the answers that have been provided with a five Likert scale. The instrument was tested first before it was used in the study. The instrument testing includes validity and reliability tests. From the test results, the valid and invalid instrument items were obtained. This study uses multiple linear regression technique models. The analysis includes normality test, significance test, linearity test, correlation, multicollinearity test, and heteroscedasticity test. The multiple linear regression model is used to determine the effect of the independent and dependent variables. So the hypothesis will be carried out using the $\mathrm{t}$-test and the $\mathrm{F}$ test, and the coefficient of determination test to determine the influence between the variables either partially or simultaneously. The application used to perform statistical calculations in this study is SPSS 25.

The hypotheses in this study are as follows: (1) Authentic leadership has a positive and significant effect on the performance of teachers of Junior High School Bekasi City; (2) The work environment has a positive and significant effect on the performance of teachers at theCity Junior High School Bekasi; and (3) authentic leadership and work environment simultaneously and significantly influence the performance of teachers of Bekasi City Junior High Schools.

\section{FINDINGS AND DISCUSSION}

\section{Prerequisite Test Analysis}

\section{1) Normality Test}

By testing normality using the Kolmogorov-Smirnov formula and using SPSS version 25 in its calculations, the Asymp.Sig (2-tailed) value of 0.200.

Table 1. Kolmogoro-Smirnov Normality Test

\begin{tabular}{llr}
\hline & & $\begin{array}{c}\text { Unstandardized } \\
\text { Residual }\end{array}$ \\
\hline $\mathrm{N}$ & Mean & 75 \\
Normal Parameters ${ }^{\mathrm{a}, \mathrm{b}}$ & Std. & .0000000 \\
& Deviation & $\mathbf{1 6 . 4 8 5 1 7 1 8 9}$ \\
& Absolute & .066 \\
Most Extreme & Positive & .065 \\
Differences & Negative & -.066 \\
Test Statistic & & .066 \\
Asymp. Sig. (2-tailed) & & $.200^{\text {c,d }}$ \\
\hline
\end{tabular}

Table 1 showed the normality test based on the results of the SPSS output. The Asymp. Sig (2-tailed) value of $0.200>0.05$. It can be concluded that the research data is normally distributed.

2) Test of Significance and Linearity

Linearity is a test to prove the existence of a linear relationship between the independent variable and the dependent variable. For example, this study has two independent variables, namely authentic leadership and work environment and the dependent variable, namely teacher performance. This significance and linearity test was calculated using SPSS version 25, and the following results were obtained: 
Table 2. Significance and Linearity Test: X1 on Y

\begin{tabular}{|c|c|c|c|c|c|c|c|}
\hline & & & $\begin{array}{c}\text { Sum of } \\
\text { Squares }\end{array}$ & $\mathrm{df}$ & $\begin{array}{c}\text { Mean } \\
\text { Square }\end{array}$ & $\mathrm{F}$ & Sig. \\
\hline \multirow{7}{*}{$\begin{array}{l}\text { Teacher } \\
\text { Performance } \\
\text { (Y)* } \\
\text { Authentic } \\
\text { Leadership } \\
\text { (X1) }\end{array}$} & Between & (Combined) & 6994.38 & 36 & 194.288 & 1.751 & .046 \\
\hline & Groups & & 2 & & & & \\
\hline & & Linearity & 3209.63 & 1 & 3209.63 & 28.9 & .000 \\
\hline & & & 2 & & 2 & 30 & \\
\hline & & Deviation from & 3784.75 & 35 & 108.136 & .975 & .529 \\
\hline & \multicolumn{2}{|c|}{ Within Groups } & $\begin{array}{r}0 \\
4215.964\end{array}$ & 38 & 110.946 & & \\
\hline & \multicolumn{2}{|l|}{ Total } & $\begin{array}{r}11210.34 \\
7\end{array}$ & 74 & & & \\
\hline
\end{tabular}

Based on The table above shows that the significance value of the authentic leadership variable $\left(\mathrm{X}_{1}\right)$ and the Teacher Performance variable $(\mathrm{Y})$ is $0.529>0.05$. Therefore, it can be concluded that there is a linear relationship between authentic leadership and performance variables.

Table 2. Significance and Linearity Test: X2 on Y

\begin{tabular}{|c|c|c|c|c|c|c|c|}
\hline & & & $\begin{array}{c}\text { Sum of } \\
\text { Squares }\end{array}$ & $\mathrm{df}$ & $\begin{array}{c}\text { Mean } \\
\text { Square }\end{array}$ & $\mathrm{F}$ & Sig. \\
\hline \multirow{6}{*}{$\begin{array}{l}\text { Teacher } \\
\text { Performance (Y)* } \\
\text { Work } \\
\text { Environment } \\
\text { (X2) }\end{array}$} & Between & (Combined) & 8709.63 & 37 & 235.395 & 3.48 & .000 \\
\hline & Groups & & o & & & 3 & \\
\hline & & Linearity & 7172.345 & 1 & 7172.345 & 106.1 & .000 \\
\hline & & $\begin{array}{l}\text { Deviation from } \\
\text { Linearity }\end{array}$ & 1537.285 & 36 & 42.702 & $\begin{array}{r}20 \\
.632\end{array}$ & .914 \\
\hline & \multicolumn{2}{|c|}{ Within Groups } & 2500.717 & 37 & 67.587 & & \\
\hline & \multicolumn{2}{|l|}{ Total } & $\begin{array}{r}11210.34 \\
7\end{array}$ & 74 & & & \\
\hline
\end{tabular}

The results of the SPSS above indicate that the significance value of the work environment variable (X2) on performance $(\mathrm{Y})$ is $0.912>0.05$ because 0.912 is more significant than 0.05 , it can be concluded that there is a linear relationship between work environment variables (X2) and Performance (Y).

3) Test Correlation Coefficient

Table 3. Correlation Coefficient Test

\begin{tabular}{cccc}
\hline \multirow{2}{*}{ Matriks } & \multicolumn{3}{c}{ Koefesien Korelasi } \\
& $\mathrm{X}_{3}$ & $\mathrm{X}_{1}$ & $\mathrm{X}_{2}$ \\
\hline $\mathrm{X}_{3}$ & 1 & 0,535 & 0,800 \\
$\mathrm{X}_{1}$ & 0,535 & 1 & 0,469 \\
$\mathrm{X}_{2}$ & 0,800 & 0,469 & 1 \\
\hline
\end{tabular}

The table above shows that the correlation between the work environment with authentic leadership r12 of 0.469. Likewise, the correlation between authentic leadership and r13 performance is 0.535 . Finally, the correlation between the work environment and teacher performance r23 is 0.800.

4) Multicollinearity Test

Multicollinearity is used to determine whether there is a correlation between independent variables. A good regression model is a model that does not have symptoms multicollinearity with a value tolerance $>0.10$ and a VIF value $<10.00$. After the multicollinearity test was carried out using SPSS version 25, the following results were obtained: 
Table 4. Multicollinearity Test

\begin{tabular}{|c|c|c|c|c|c|c|c|c|}
\hline \multirow{2}{*}{\multicolumn{2}{|c|}{ Model }} & \multicolumn{2}{|c|}{$\begin{array}{l}\text { Unstandardised } \\
\text { Coefficients }\end{array}$} & \multirow{2}{*}{$\begin{array}{l}\text { Standardise } \\
\mathrm{d} \\
\text { Coefficients } \\
\text { Beta }\end{array}$} & \multirow[t]{2}{*}{$\mathrm{t}$} & \multirow[t]{2}{*}{ Sig. } & \multicolumn{2}{|c|}{$\begin{array}{l}\text { Collinearity } \\
\text { Statistics }\end{array}$} \\
\hline & & B & $\begin{array}{l}\text { Std. } \\
\text { Error }\end{array}$ & & & & $\begin{array}{c}\text { Tolera } \\
\text { nce }\end{array}$ & VIF \\
\hline \multirow[t]{3}{*}{1} & (Constant) & 7.844 & 11.028 & & .711 & .479 & & \\
\hline & $\begin{array}{l}\text { Authentic } \\
\text { Leadership (X1) }\end{array}$ & .172 & .064 & .205 & 2.684 & .009 & .780 & $\begin{array}{l}1.2 \\
82\end{array}$ \\
\hline & $\begin{array}{l}\text { Work Environment } \\
\text { (X2) }\end{array}$ & .755 & .082 & .704 & 9.216 & .000 & .780 & $\begin{array}{r}1.2 \\
82\end{array}$ \\
\hline
\end{tabular}

The results of the table above show that the tolerance value is $0.780>0.10$. Therefore, it means that there are no symptoms of multicollinearity in this study. In addition, decision making can also be done by looking at the VIF value. Because the VIF value is $1.282<10.00$, it can be concluded that there are no symptoms of multicollinearity in this research model.

5) Heteroscedasticity Test

Heteroscedasticity is used to determine whether a regression model has a variant value fixed residual from one observation to another. The heteroscedasticity test in this study uses the Rank Spearman test based on decision making if the value is significant or sig. (2-tailed). It is greater than 0.05, so there is no problem with heteroscedasticity. After calculating using SPSS version 26, the following results were obtained:

Table 5. Heteroscedasticity Test

\begin{tabular}{|c|c|c|c|c|c|}
\hline \multirow[t]{2}{*}{ Model } & \multicolumn{2}{|c|}{$\begin{array}{c}\text { Unstandardised } \\
\text { Coefficients }\end{array}$} & \multirow{2}{*}{$\begin{array}{c}\begin{array}{c}\text { Standardised } \\
\text { Coefficients }\end{array} \\
\text { Beta } \\
\end{array}$} & \multirow[t]{2}{*}{$\mathrm{t}$} & \multirow[t]{2}{*}{ Sig. } \\
\hline & $\mathrm{B}$ & Std. Error & & & \\
\hline 1 (Constant) & 1.493 & 6.988 & & .214 & .831 \\
\hline $\begin{array}{l}\text { Authentic Leadership } \\
\text { (X1) }\end{array}$ & -.034 & .041 & -.110 & -.833 & .408 \\
\hline $\begin{array}{l}\text { Work Environment } \\
\text { (X2) }\end{array}$ & .059 & .052 & .151 & 1.141 & .258 \\
\hline
\end{tabular}

Based on the table above, it can be seen that the Sig value. (2-tailed) for authentic leadership is 0.408 , which is more significant ( $>$ ) than 0.05. Then, the Sig. (2-tailed) for the work environment is 0.258 , which is more significant $(>)$ than 0.05. Because the two significance values obtained are more significant than 0.05 , it can be concluded that there is no heteroscedasticity problem in this regression model.

\section{Multiple Linear Regression Analysis}

After using SPSS version 25 to search for a multiple linear regression model for this study, the results are as follows:

Table 6.Regression Test

\begin{tabular}{lc}
\hline \hline Variable & Regression Coefficient \\
\hline Constant & 7.844 \\
Authentic Leadership (X1) & 0,172 \\
Work Environment (X2) & 0,755 \\
\hline \hline
\end{tabular}

From these results it can be concluded that the regression equation model in this study is: $\mathrm{Y}$ $=7.844+0.72+0.755$. Then also had a coefficient of determination of this equation:

Table 7. Coefficient of Determination Test

\begin{tabular}{ccccccc}
\hline \multirow{2}{*}{ Variable } & \multirow{2}{*}{ rxixj } & \multirow{2}{*}{ Pij } & Direct Effect & \multicolumn{2}{c}{ Indirect Effect } & R2 \\
\hline $\mathrm{X} 1$ & 0,469 & 0,205 & 0,042 & 0 & 0,068 & 0,11 \\
$\mathrm{X} 2$ & & 0,704 & 0,495 & 0,068 & 0 & 0,563 \\
& & & 0,537 & 0,021 & 0,021 & 0,673 \\
& Total & & & & & \\
\hline
\end{tabular}


From the results above, it can be seen that the coefficient of determination from this regression equation. The coefficient value shows how much influence the independent variable has on the dependent variable simultaneously. From the results obtained, it is known that the coefficient of determination is 0.673 or $67.3 \%$. It means that the authentic leadership variable (X1) and the work environment variable (X2) simultaneously influence the teacher performance variable (Y) by $67.3 \%$. In contrast, the other $33.6 \%$ are influenced by other variables which are not researched.

\section{Hypothesis Test}

1) T-test

Table 8. t-test

\begin{tabular}{|c|c|c|c|c|c|c|}
\hline \multirow{2}{*}{\multicolumn{2}{|c|}{ Model }} & \multicolumn{2}{|c|}{$\begin{array}{l}\text { Unstandardised } \\
\text { Coefficients }\end{array}$} & \multirow{2}{*}{$\begin{array}{c}\text { Standardised } \\
\text { Coefficients } \\
\text { Beta }\end{array}$} & \multirow[t]{2}{*}{$\mathrm{t}$} & \multirow[t]{2}{*}{ Sig. } \\
\hline & & $\mathrm{B}$ & Std. Error & & & \\
\hline \multirow[t]{3}{*}{1} & (Constant) & 7.844 & 11.028 & & .711 & .479 \\
\hline & $\begin{array}{l}\text { Authentic Leadership } \\
\text { (X1) }\end{array}$ & .172 & .064 & .205 & 2.684 & .009 \\
\hline & $\begin{array}{l}\text { Work Environment } \\
\text { (X2) }\end{array}$ & .755 & .082 & .704 & 9.216 & .000 \\
\hline
\end{tabular}

The results obtained above show that authentic leadership (X1) and work environment (X2) partially affect teacher performance. It can be seen from the significance value of each independent variable. The significance of the authentic leadership variable is 0.009 , which is smaller $(<)$ than 0.05. In addition, the $t$-value for authentic leadership variables is 2.684 greater $(>)$ than $t$-table 1.666. Therefore, it can be concluded that authentic leadership (X1) affects teacher performance. The work environment variable (X2) with a value of 0.000 is also smaller $(<)$ than 0.05 . The $t$-count value of the work environment variable is 9,216, which is more significant $(>)$ than the t-table of 1.666. Therefore, it shows a positive influence between work environment and performance.

2) F test

Table 9. F -test

\begin{tabular}{llcccc}
\hline \hline Model & $\begin{array}{l}\text { Sum } \\
\text { Square }\end{array}$ & Df & Mean Square & F & Sig \\
\hline Regression & 7539.657 & 2 & 3769.829 & 73.945 & $\begin{array}{c}\text { O,oo } \\
\text { O }\end{array}$ \\
\hline Residual & 3670.690 & 72 & 50.982 & & \\
\hline Total & 11210.347 & 74 & & & \\
\hline
\end{tabular}

From the table above, it can be seen that authentic leadership and work environment influences teacher performance simultaneously. It can be seen from the significance value (Sig.) Which is equal to 0.000 , which is smaller $(<)$ than 0.05. In addition, conclusions can be drawn by looking at the F-count value. F-count value of 73,945 is more excellent ( $>$ ) than F-table 3.12. From these results, it can be concluded that authentic leadership and work environment simultaneously affect teacher performance. It can be seen from the significance value of the $\mathrm{F}$ test of 0.000. This value is smaller $(<)$ than 0.05 , which means an effect of authentic leadership and work environment simultaneously on teacher performance. The value of the F-count is 73,945, which is also greater $(>)$ than F-table, which is worth 3.12. the effect of these two variables is $30.1 \%$ on teacher performance. It indicated by the value of $\mathrm{R} 2=0.673$. Therefore, it can be concluded that authentic leadership and work environment have a simultaneous and significant effect on the performance of City State Junior High School teachers, which means that this research hypothesis is accepted. Related research on the effect of authentic leadership on performance was carried out by Wong \& Laschinger (2012), Authentic leadership, performance, and job satisfaction: The mediating role of empowerment. The results of his research indicate that: The direct effect of authentic leadership on 
performance has an effect of 0.042 . These results prove that the influence of the leadership variable is minimal on teacher performance. In line with this study, the research results from Wong \& Laschinger (2012) prove the same results; namely, there is a small positive influence with an influence value of 0 , 08 .

While for the influence of the work environment on the performance of obtaining a value of 0.495, this proves that the work environment affects the performance of teachers by $49.5 \%$, this is in line with the results of research from Firdaus (2018) obtaining a simple regression value, namely the correlation number of 0.438 which is the standard coefficient. It means that if the agency makes positive changes to the work environment, employee performance will increase

Authentic leadership theory proposes that authentic leadership's essential effects on the work environment and performance. What is new in this theory is the critical mediating effect of structural empowerment between authentic leadership and work environment and performance. These results indicate that managers who emphasise transparency, balanced processing, selfawareness, and high ethical standards also effectively increase nurses' perceptions of workplace empowerment, improving their performance and work environment. Thus, authentic leadership in an important sense influences the work environment and performance. What is new about this theory is the crucial mediating effect of structural empowerment between authentic leadership, work environment and performance.

The results of the total effect of endogenous variables, authentic leadership and work environment on teacher performance obtained results of 0.11 or $11 \%$ for authentic leadership variables, 0.562 or $56.2 \%$ for work environment variables, meaning that the effect of the work environment is more significant on teacher performance. Therefore, the total exogenous effect is 0.673 or $67.3 \%$. Furthermore, there is an indirect effect of 0.068 obtained through the correlation of other exogenous variables.

\section{CONCLUSION}

This study found that schools must pay attention to the teacher performance produced based on the influence of the school principal's leadership and the surrounding work environment. The role of the principal is significant in responding to all decisions made because these decisions will affect all stakeholders in the school. Through an authentic leadership style, the principal can provide a good role model for the entire community in the school environment. In this study, there are still many shortcomings and weaknesses due to the limitations of researchers to examine more deeply related to the variables that the researchers took. This is due to limited time, energy, and costs in the research process in the field. Nevertheless, it is hoped that the results of this study can be used as a reference. Researchers who will take the same variables can even be developed through other variables that the researcher does not research.

\section{REFERENCES}

Armstong, M. (2020). handbook of performance management (6th edition). British Library.

Colquitt, J. A., Lepine, J. A., \& Wesson, M. J. (2017). Organisational Behavior: Improving performance and commitment in the workplace. In Practice Development in Health Care (Sixth Edit, Vol. 4, Issue 4). McGraw-Hill. https://doi.org/10.1002/pdh.22

Darvish, H., \& Rezaei, F. (2011). The Impact Of Authentic Leadership On Job Satisfaction And Team. Management \& Marketing Challenges for the Knowledge Society, 6(3), 421-436.

Demus, A. w, Kindangen, P., \& Tielung, M. V. . (2015). The impact of work environment on employee performance ( case study at pt . Bank artha graha international tbk, manado branch calaca ). international business administrarion, 15(05), 818-827.

Firdaus, A. (2018). Pengaruh Kepemimpinan Autentik Terhadap Work Engagement Melalui Psychological Capital Sebagai Variabel Intervening (Studi Pada Karyawan Bagian Kantor PT. Perkebunan Nusantara X Pabrik Gula Lestari Di Nganjuk). Jurnal Ilmu Manajemen (JIM), 6(3), 288-295.

George, J. M., \& Jones, G. R. (2012). Understanding and Managing Organizational Behavior (S. Yagan (ed.); Sixth Edit). Pearson. 
Gibson, J. L., Ivancevich, J. M., Donnelly, J. H., \& Konopaske, R. (2009). Organisations: Behavior, Structure, Processes (Fourteenth). McGraw-Hill.

Lestary, L. (2017). Pengaruh Lingkungan Kerja Terhadap Kinerja Karyawan. Jurnal Riset Bisnis Dan Investasi, 3(2).

Okasheh, H., \& AL-Omari, K. (2017). The Influence of Work Environment on Job Performance: A Case Study of Engineering Company in Jordan. International Journal of Applied Engineering Research, 12(24), 15544-15550.

Purwanto, A., Sopa, A., Primahendra, R., Kusumaningsih, S. W., \& Pramono, R. (2020). Pengaruh Gaya Kepemimpinan Transactional , Transformational , Authentic Dan Authoritarian Terhadap Kinerja Guru. Jurnal Manajemen Pendidikan Islam, 04(01), 70-80.

Raso, R., Fitzpatrick, J. J., \& Masick, K. (2020). Clinical nurses' perceptions of authentic nurse leadership and healthy work environment. Journal of Nursing Administration, 5O(9), 489494. https://doi.org/10.1097/NNA.0000000000000921

Ribeiro, N., Gomes, D. R., \& Kurian, S. (2018). Authentic leadership and performance : The mediating role of employees' affective commitment. Social Responsibility Journal, March. https://doi.org/10.1108/SRJ-06-2017-0111

Robbins, S. P., \& Judge, T. A. (2013). Organisational Behavior (15th editi). Pearson. https://doi.org/10.1007/BFo1148546

Robbins, S. P., \& Judge, T. A. (2017). Organisational Behavior, Seventeenth Edition, Global Edition. Pearson Education Limited, 747.

Wang, H., Sui, Y., Luthans, F., Wang, D., \& Wu, Y. (2014). Impact of authentic leadership on performance: Role of followers' positive psychological capital and relational processes. Journal of Organizational Behavior, 35(1), 5-21. https://doi.org/10.1002/job.1850

Wong, C. A., \& Laschinger, H. K. S. (2012). role of empowerment. Huston 2008. https://doi.org/10.1111/j.1365-2648.2012.06089.x 